\title{
Fallen leaves on the water-bed: diurnal camouflage of three night active fish species in an Amazonian streamlet
}

\author{
Ivan Sazima*, Lucélia Nobre Carvalho**, \\ Fernando Pereira Mendonça**, and Jansen Zuanon**
}

Resemblance to dead leaves is a well known type of camouflage recorded for several small vertebrates that dwell in the leaf and root litter on the ground. We present here instances of such resemblance in three species of nocturnal fishes (Siluriformes and Gymnotiformes) that spend the daytime among submersed root-tangle with leaf litter in Amazonian streams. All three species are very difficult to spot visually, due both to their shape and colors which blend with the substrate, as well as to the heterogeneous nature of their cover. Two species were recorded to lie on their sides, which adds to their resemblance to dead leaves. When disturbed, one species may drift like a waterlogged leaf, whereas another moves upwards the root-tangle, exposing its fore body above the water surface. We regard their leaf-like shapes, cryptic colors, and escape movements as a convergence in defensive responses to visually hunting aquatic vertebrates, most likely diurnal predaceous fishes.

Semelhança com folhas mortas é um tipo bem conhecido de camuflagem, presente em diversos pequenos vertebrados que vivem em meio à serapilheira do chão da floresta. Apresentamos aqui exemplos deste tipo de semelhança em três espécies de peixes de hábitos noturnos (Siluriformes e Gymnotiformes) que permanecem durante o dia em meio a aglomerados de raízes e folhas submersas em igarapés amazônicos. As três espécies são difíceis de localizar visualmente, tanto devido ao formato e cores, que se confundem com o substrato, como pela heterogeneidade estrutural dos seus abrigos. Duas espécies foram observadas deitadas de lado durante o dia, o que aumenta sua semelhança com folhas mortas. Quando perturbada, uma das espécies deixa-se levar à deriva como uma folha semi-encharcada, ao passo que outra espécie se desloca para cima, nos aglomerados de raízes, expondo a porção anterior do corpo acima da superfície da água. Consideramos o formato semelhante a uma folha, as cores crípticas e os movimentos de fuga, como uma convergência de respostas defensivas a vertebrados aquáticos que caçam visualmente orientados, provavelmente peixes predadores de hábitos diurnos.

Key words: Crypsis, leaf resemblance, defence against predators, Siluriformes, Gymnotiformes.

\section{Introduction}

Resemblance to dead leaves is a well known type of crypsis recorded for several small vertebrates that dwell in the leaf and root litter of the forest floor (Cott, 1940; Edmunds, 1974). This defence type contains both camouflaging and disruptive colour components and is regarded as effective against visually guided predators (Edmunds, 1974; Vane-Wright, 1976). Different cryptic animals that live in the same habitat usually have similar shapes and colors, in remarkable instances of convergence (e.g., Cott, 1940). Fishes that resemble dead leaves are known both from freshwater and marine environments, this disguise being used both for defence and hunting (e.g., Cott, 1940; Breder, 1946; Randall \& Randall, 1960).
We present here instances of resemblance to dead leaves in three species of nocturnal fishes that spend the daytime among submersed root-tangle with leaf litter in Amazonian streams. We regard their cryptic colors, leaf-like shapes, and escape movements as a convergence of defensive responses to visually hunting aquatic vertebrates, most likely diurnal predaceous fishes.

\section{Material and Methods}

Field observations were conducted in July and August 2004, and September 2005, totaling 4 days in an unnamed clear-water igarapé (forest stream), a $2^{\text {nd }}$ order tributary of the Rio Cuieiras in the Rio Negro drainage in Central Amazonia

*Departamento de Zoologia and Museu de História Natural, Caixa Postal 6109, Universidade Estadual de Campinas, 13083-970 Campinas, São Paulo, Brazil. e-mail: isazima@unicamp.br

**CPBA, Caixa Postal 478, INPA-Instituto Nacional de Pesquisas da Amazônia, 69083-970 Manaus, Amazonas, Brasil 
(see Zuanon \& Sazima, 2004 for photograph and site description). For a map and additional information about the study area see Bührnheim \& Cox-Fernandes (2001), and Gascon \& Bierregaard (2001).

Behaviour of the fishes was recorded directly and photographed during daytime as well as night time in 5 underwater sessions while snorkelling (Sazima, 1986). "Focal animal" and "all occurrences" samplings (Lehner, 1998) were used throughout the study, totaling 130min of behavioral records in situ. Underwater flashlights were used for night observations. For additional observations and some of the underwater photographs a mesh enclosure that accommodated one observer was mounted on the stream bed. Under these circumstances, the proneness to lie on its side was tested for the three species: we carefully handled the fishes underwater and put them lying on their sides on the leaf litter or the root-tangle. Vouchers are in the fish collections of the Instituto Nacional de Pesquisas da Amazônia (INPA 250107, 250108, 25111) and the Museu de História Natural da Universidade Estadual de Campinas (ZUEC 5930, 6297, 6298). Due to their resemblance to dead leaves and escape behaviour, we propose here the English common names "Drifting-leaf catfish" for Tetranematichthys quadrifilis, "Leaf-catfish" for Helogenes marmoratus, and "Leaf-knifefish" for Steatogenys duidae.

\section{Results}

The catfishes Tetranematichthys quadrifilis (Auchenipteridae), Helogenes marmoratus (Cetopsidae), and the knifefish Steatogenys duidae (Hypopomidae) bear morphological and color resemblances to the components of the roottangle with leaf litter they rest at daytime. While within the root-tangle all three species are very difficult to spot visually, due both to their shape and colors which blend with the substrate, as well as to the heterogeneous nature of their cover (Fig. 1). Especially impressive is the colour pattern of $T$. quadrifilis and $H$. marmoratus, which resembles that of dead leaves (Fig. 2). In both species the fins have a colour similar to that of the body. The mottled pattern and the high and short body of S. duidae favor its resemblance to a dead leaf (Fig. 1).

While within the leaf litter layers anchored on roots or branches in the stream bed at daytime, both T. quadrifilis and $S$. duidae were recorded to lie on their sides (Fig. 2). The three species have strongly compressed body, which adds to their resemblance to dead leaves.

When its diurnal shelter was disturbed, T. quadrifilis left the debris and drifted like a waterlogged leaf moving slowly in the water flow, with no apparent movements of its fins. Similar but less pronounced behaviour was recorded for $S$.

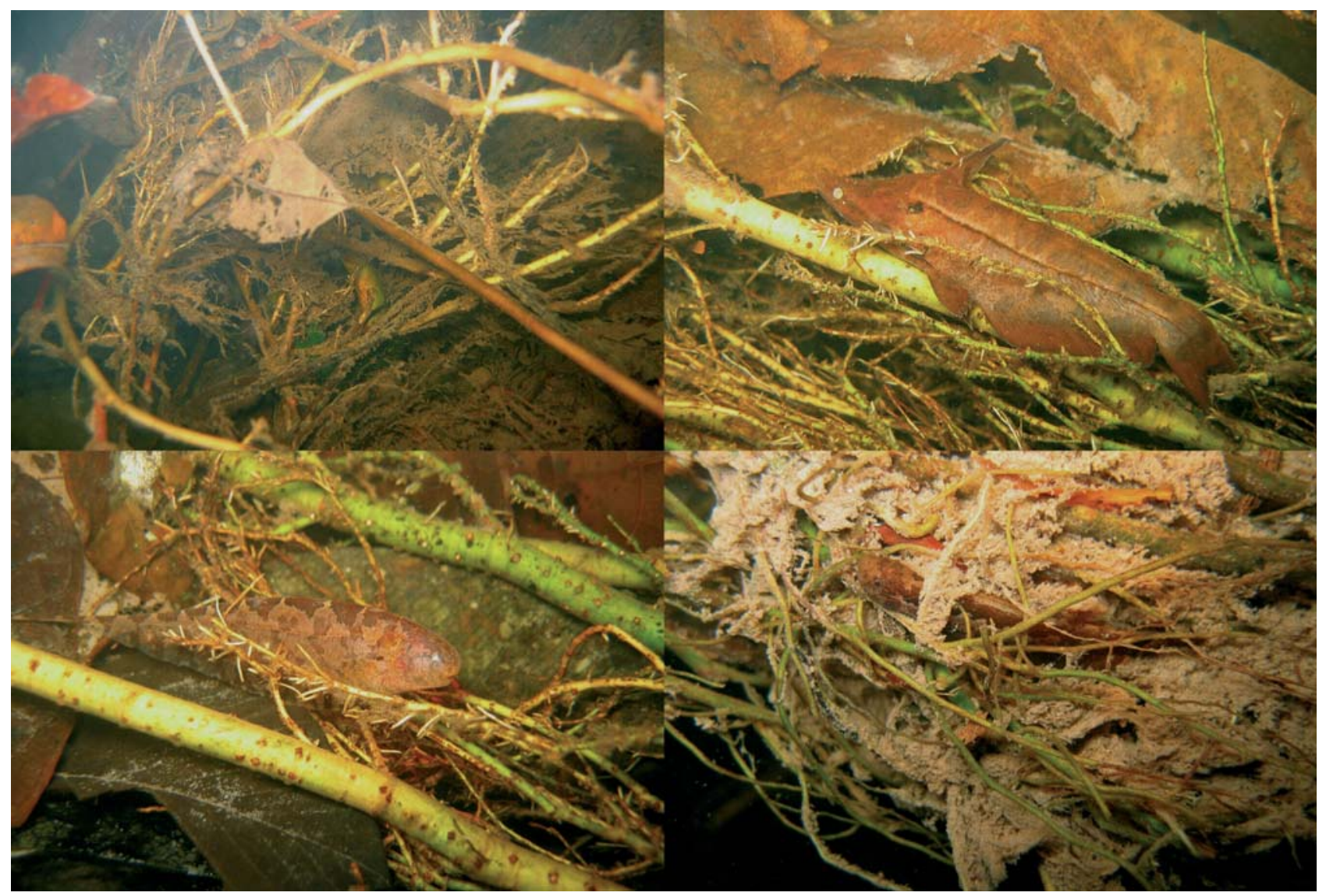

Fig. 1. Habitat and aspect of three root-tangle and leaf-litter inhabiting fish species photographed underwater in an Amazonian streamlet: Tetranematichthys quadrifilis (77.7 mm SL, INPA 25107, top right), Steatogenys duidae (129.2 $2 \mathrm{~mm}$ TL, INPA 25018, bottom left), and Helogenes marmoratus (59.8 mm SL, INPA 25111, bottom right). 
duidae, which drifted in an oblique position towards the debris-littered bottom, its anal fin undulating. On the other hand, $H$. marmoratus moved upwards the root-tangle, exposing its head or fore body above the water surface (Fig. 2) even at nightfall. If disturbed further, it quickly swam in an upright position towards the nearest debris shelter (but see Le Bail et $a l ., 2000$ for sidelong swimming). At night both catfish species moved near the surface apparently foraging. No knifefish was recorded at night.

In our simple daytime field tests $T$. quadrifilis was the species most prone to lie on its side (Fig. 2), whereas $H$. marmoratus and $S$. duidae quickly resumed their upright position among the root-tangle.

\section{Discussion}

The best known examples of resemblance of fishes to dead leaves are given by one freshwater species, Monocirrhus polyacanthus (Polycentridae) and two saltwater ones, Platax orbicularis (Ephippidae) and Lobotes surinamensis (Lobotidae). However, these are diurnally active fishes (e.g., Breder, 1946; Randall \& Randall, 1960; Carvalho-Filho, 1999; Britz \& Kullander, 2003) that use this crypsis type both for defence and for hunting their prey (aggressive camouflage, see Cott, 1940). The dead leaf disguise for hunting is particularly well documented for Monocirrhus polyacanthus, which moves unobtrusively towards the intended prey using its transparent fins (e.g., Cott, 1940; Britz \& Kullander, 2003).

On the other hand, the three instances presented here relate to fish species that are nocturnally active foragers (Vari \& Ortega, 1986; Sabino \& Zuanon, 1998; JZ, pers. obs.) while moving upstream. Thus, their leaf resemblance most probably is used for defence only, both at daytime (all three species while resting) and at night time (T. quadrifilis while drifting downstream). Drifting as a defence is recorded for several small fishes with dead leaf or debris-like aspect (e.g., Breder, 1946; Randall \& Randall, 1960; Sazima \& Carvalho-Filho, 2003).

Lying on its side within aquatic leaf litter is already known for H. marmoratus (Le Bail et al., 2000) and was recently recorded for some species of the trichomycterid genus Listrura (IS, pers. obs.). Thus, leaf resemblance and the tendency to lie on the side is known for at least three distinct groups of Siluriformes and is likely related to their morphology (laterally compressed body and long anal fin), which improves the camouflaging effect within the root-tangle and leaf debris.

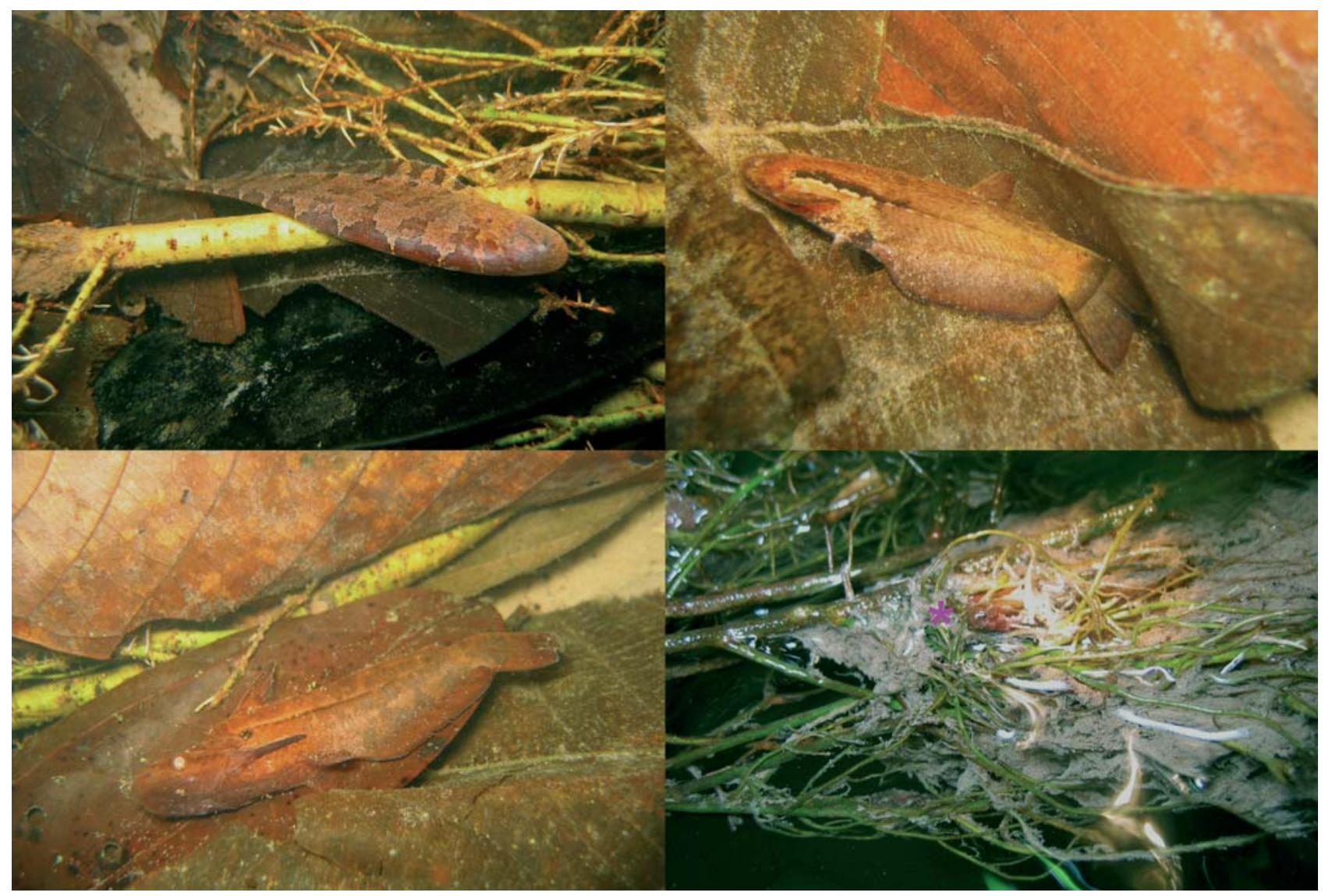

Fig. 2. Three leaf-shaped and cryptically colored fish species photographed underwater lying on their sides, and one escape response out of the root-tangle: Steatogenys duidae (top left), Helogenes marmoratus (top and bottom right), and Tetranematichthys quadrifilis (bottom left). Note body shape and color resemblance to dead leaves in the three species, as well as the fore body of H. marmoratus above the water surface in the bottom right picture (mauve asterisk). 
Exposition out of the shelter and above water surface and remaining still, as here recorded for Helogenes marmoratus, is uncommonly recorded as a defensive response in Neotropical freshwater fishes (but see Sazima \& Machado, 1989, for the cichlid Laetacara dorsigera). Besides our records, Lima et al. (2005) note that $H$. marmoratus jumps on the bank during rotenone fishing by Tukano and Tuyuka indigenous people, then jumping back to the stream after water renovation.

Taken together, the cryptic color patterns, the leaf-like shapes, and the escape movements of the three fish species recorded here may be viewed as defensive responses to diurnal, visually hunting aquatic vertebrates, most likely predaceous fishes. Species of the syntopic cichlid genera Crenicichla and Cichla, which live in the same or similar habitats in Central Amazon (Sabino \& Zuanon, 1998) are likely predator candidates (C. lepidota was recorded searching for prey by disturbing the leaf-litter on the bottom in the Pantanal region, Central Brazil - IS, pers. obs.). The defensive value of this crypsis type may be tested with use of enclosures in the habitat, or in suitably monted aquaria, in presence of a potential predator fish. We regard the instances of crypsis presented here as a convergence among sympatric, small, and nocturnally active fishes that rest at daytime among roottangle with leaf litter in Neotropical streams.

\section{Acknowledgements}

We thank C. Sazima for valuable suggestions on the manuscript; the Biological Dynamics of Forest Fragments Project (INPA/Smithsonian) for logistical and financial support; the CNPq, FAPEAM, FAPESP, and Fundação O Boticário for essential financial support. Contribution 458 of the BDFF Project, and 05 of the Ygarapés Project.

\section{Literature cited}

Breder, C. M. 1946. An analysis of the deceptive resemblance of fishes to plant parts, with critical; remarks on protective coloration, mimicry and adaptation. Bulletin of the Bingham Oceanographic Collection 10(2): 1-49.

Britz, R \& S. O. Kullander. 2003. Family Polycentridae (Leaffishes). Pp. 603-604. In: Reis, R. E., S. O. Kullander \& C. A. Ferraris, Jr. (Eds). Check list of the freshwater fishes of South and Central America. Porto Alegre, Edipucrs, 729p.

Bührnheim, C. M. \& C. Cox-Fernandes. 2001. Low seasonal variation of fish assemblages in Amazonian forest streams. Ichthyological Explorations of Freshwaters. 12 (1): 65-78.
Carvalho-Filho, A. 1999. Peixes: costa brasileira. $3^{\text {a }}$ ed. São Paulo, Melro, 283p.

Cott, H. B. 1940. Adaptive coloration in animals. London, Methuen, $508 \mathrm{p}$.

Edmunds, M. 1974. Defence in animals. Harlow, Longman, 357 pp.

Gascon, C. \& R. O. Bierregaard. 2001. The biological dynamics of forest fragments project. Pp. 31-42. In: Bierregaard, R. O., C. Gascon, T. E. Lovejoy \& R. C. G. Mesquita (Eds.). Lessons from Amazonia, the ecology and conservation of a fragmented forest. New Haven, Yale University Press, 478 pp.

Le Bail, P.-Y, P. Keith \& P. Planquette. 2000. Atlas des poissons d'eau douce de Guyane. Tome 2, fascicule II: Siluriformes. Patrimoines naturels (M.N.H.N/SPN), 43 (II), 307p

Lehner, P. N. 1998. Handbook of ethological methods. $2^{\text {nd }}$ ed. New York, Cambridge University Press, 672p.

Lima, F. C. T., L. Ramos, T. Barreto, A. Cabalzar, G. Tenório, A. Barbosa, F. Tenório \& A. S. Resende. 2005. Peixes do Alto Tiquié. Pp. 111-282. In: Cabalzar, A. (Ed.). Peixe e gente no Alto Rio Tiquié: Conhecimentos Tukano e Tuyuka, ictiologia e etnologia. São Paulo, Inst. Socioambiental, 339 p.

Randall J. E. \& H. A. Randall. 1960. Examples of mimicry and protective resemblance in tropical marine fishes. Bulletin of Marine Science of the Gulf and Caribbean, 10: 444-480.

Sabino, J \& J. Zuanon. 1998. A stream fish assemblage in Central Amazonia: distribution, activity patterns, and feeding behavior. Ichthyological Explorations of Freshwaters, 8(3): 201-210.

Sazima, I. 1986. Similarities in feeding behaviour between some marine and freshwater fishes in two tropical communities. Journal of Fish Biology, 29(1): 53-65.

Sazima, I. \& A. Carvalho-Filho, 2003. Natural history of the elusive blenny Lupinoblennius paivai (Perciformes: Blenniidae) in coastal streams of southeast Brazil. Ichthyological Exploration of Freshwaters 14(2):175-184.

Sazima, I \& F. A. Machado. 1989. Melhor em seco que na água: uma tática defensiva do peixe Laetacara dorsigera (Cichlidae). Ciência e Cultura, 47(1): 1014-1016.

Vane-Wright, R. I. 1976. A unified classification of mimetic resemblances. Journal of Linnean Society, London, 8(1): 25-56.

Vari, R. P. \& H. Ortega. 1986. The catfishes of the Neotropical family Helogenidae (Ostariophysi: Siluroidei). Smithsonian Contributions to Zoology, 442: 1-20.

Wickler, W. 1968. Mimicry in plants and animals. New York, McGraw, 255p.

Zuanon, J. \& I. Sazima. 2004. Natural history of Stauroglanis gouldingi (Siluriformes: Trichomycteridae), a miniature sanddwelling candiru from central Amazonian streamlets. Ichthyological Exploration of Freshwaters, 15(3): 201-208.

Received October 2005 Accepted February 2005 